\title{
Optimization design of enclosure structure of solar energy building in Northwest China based on indoor zoning
}

\author{
Xiaona Fan ${ }^{a}$, Yiyun Zhu ${ }^{\text {band Guochen Sang }}{ }^{\mathrm{c}^{*}}$
}

\author{
School of Civil Engineering and Architecture, Xi'an University of Technology, Xi'an 710048, China \\ aemail:1138982669@qq.com, ${ }^{\mathrm{b}}$ email:zyyun@xaut.edu.cn, ${ }^{\mathrm{c}^{*}}$ email:sangguochen@xaut.edu.cn
}

\begin{abstract}
Key words: Northwest Rural solar building, thermal environment, thermal parameters, optimization design
\end{abstract}

\begin{abstract}
Indoor thermal conditions and structure features of the construction of rural dwellings in Northwest China were investigated and tested, the results show that the rural building duo to lack of scientific and systematic thermal design, the thermal properties of building envelope structure is poor, the indoor thermal environment in winter is not ideal, and the residents of thermal comfort satisfaction is low. According to the local climatic conditions and residential characteristics, by using Design Builder software to analyze the influence of enclosure structure on each function room temperature of under the indoor partition function control mode, to obtain the best practice of enclosure structure and thermal parameters, and comparative analysis is made of the indoor temperature changes by adopting design strategies before and after. The results show that the average indoor temperature of the south room is increased by $3.9^{\circ} \mathrm{C}$ and the temperature fluctuation is reduced by $0.7^{\circ} \mathrm{C}$ after adopting the suitable design technique of enclosure structure.; meantime, the average indoor temperature of the south room is increased by $4.2{ }^{\circ} \mathrm{C}$ and the temperature fluctuation is reduced by $2.9^{\circ} \mathrm{C}$ after adopting the suitable design technique of enclosure structure, In the natural condition of each function room indoor thermal environment quality can reach the demand of residents for indoor thermal comfort standards, the research will provide a useful exploration for the design of rural solar energy buildings in Northwest China or other similar areas.
\end{abstract}

\section{Introduction}

The Northwest China is located in the cold and cold climate zone. The climate is bad, the ecological environment is fragile, and the winter is cold and long. Due to the large number of rural residents, the total amount of rural residential buildings is large and wide, but the building form is simple and the structure is extensive, and the indoor thermal environment is poor in winter [1,2]. Corresponding to the harsh natural conditions, the northwest region is rich in solar energy resources and has the advantage of developing solar heating buildings [3]. The development of passive solar heating buildings according to local conditions plays a positive role in solving the contradiction between heating energy utilization and ecological protection of rural buildings in the ecologically fragile areas of Northwest china. Up to the present, solar energy building has been developed for forty years in our country. However, there are still some shortcomings in the field of thermal design, such as the one-sided region and the integration of space. The solar energy utilization effect is not ideal.

In recent years, many scholars have also studied the characteristics of solar heating buildings and residents in rural areas of Northwest china. But the existing researches are more general ideas and methods, and the geographical characteristics of the building and the lack of spatial considerations $[4,5,6]$; and the stability of the indoor temperature and different functional rooms on 
the thermal environment quality requirements of the differences Less [7,8]. In addition, how to use passive technology to optimize indoor heat distribution, improve the quality of thermal environment, and solve the contradiction between heating energy supply and demand mismatch, have not yet been systematically reported. In view of, based on the rural residential area of Ningxia as the research object, through investigation, test, theoretical analysis and numerical simulation, to analyze the influence of enclosure structure on each function room temperature of under the indoor partition function control mode and obtain the best practice of enclosure structure and thermal parameters, also the indoor temperature changes before and after optimization are compared and analyzed. The research will provide a useful exploration for the design of rural solar energy buildings in Northwest China or other similar areas.

\section{Rural residential buildings and thermal environment in Northwest China}

In the middle of January 2015, the research team conducted a field survey on the representative solar energy rich areas of Ningxia in Northwest China, it was found that the rural dwellings in this area can be divided into two categories: raw soil houses and brick houses, of which $13 \%$ of raw land, brick houses accounted for $87 \%$. The research also found that the brick houses by oneself are mostly face north, the east-west axis long and north-south axis short, the exterior walls are $370 \mathrm{~mm}$ solid clay bricks with flat roofs or double sloping roofs, the building is only south to the window and the window type is single layer single frame aluminum alloy window or single layer single frame plastic window. It can be seen that the use of passive solar energy has been taken into account in the construction of the brick concrete houses built in the area.

To further explore the utilization effect of building solar energy research group selected a representative building, the research team selected a representative building, and carried out indoor and outdoor environmental test in December 17th of that year, during the test, there is no auxiliary heat source in the room, and the test time is 24 hours of continuous testing, the measuring point plan shown in Fig. 1, the test results shown in Fig. (2-4).

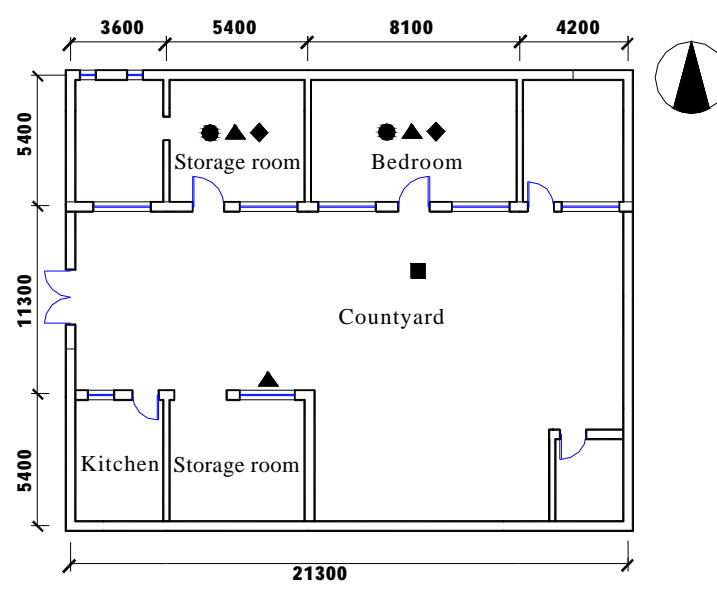

Note: - Solar radiometer; $\boldsymbol{\Delta}$ Temperature and humidity recorder

- Hot-wire anemometer; • Block globe temperature recorder

Fig. 1, Typical building plan and layout of measuring points

The changes of outdoor temperature and solar radiation intensity during the test are shown in Fig. 2 and Fig. 3, respectively. 


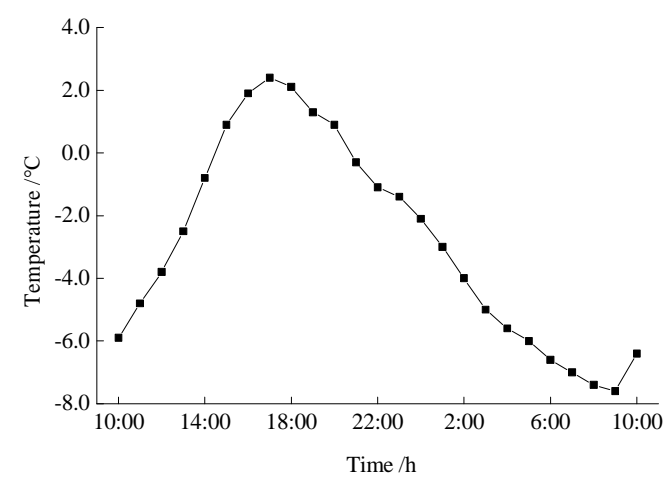

Fig. 2, Outdoor air temperature

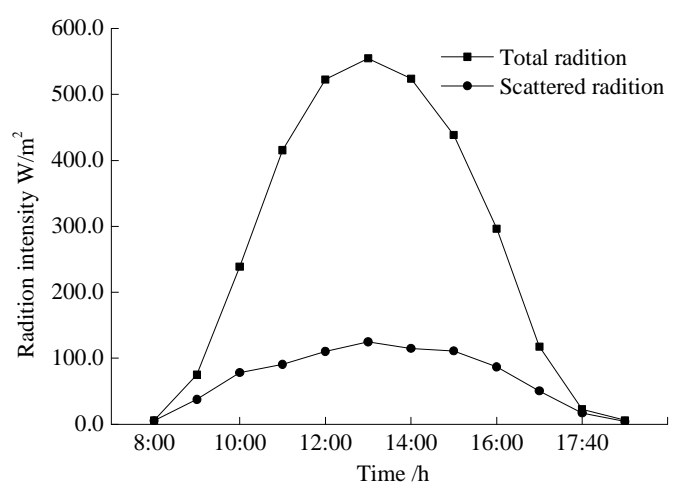

Fig. 3, Solar radiation intensity

It can be seen from Fig. 2, the outdoor temperature is rising at 8:30 am - 5:00 pm, and the outdoor temperature is decreasing at 5:00 pm - 8:30 in the next day; the average outdoor temperature is $-2.7^{\circ} \mathrm{C}$, the temperature range of -7.6 to $2.5^{\circ} \mathrm{C}$, the temperature fluctuation is $10.1^{\circ} \mathrm{C}$. It can be seen that the area is cold in winter and the temperature fluctuation is larger in day.

The change of indoor temperature and humidity during the test is shown in Fig. 4.

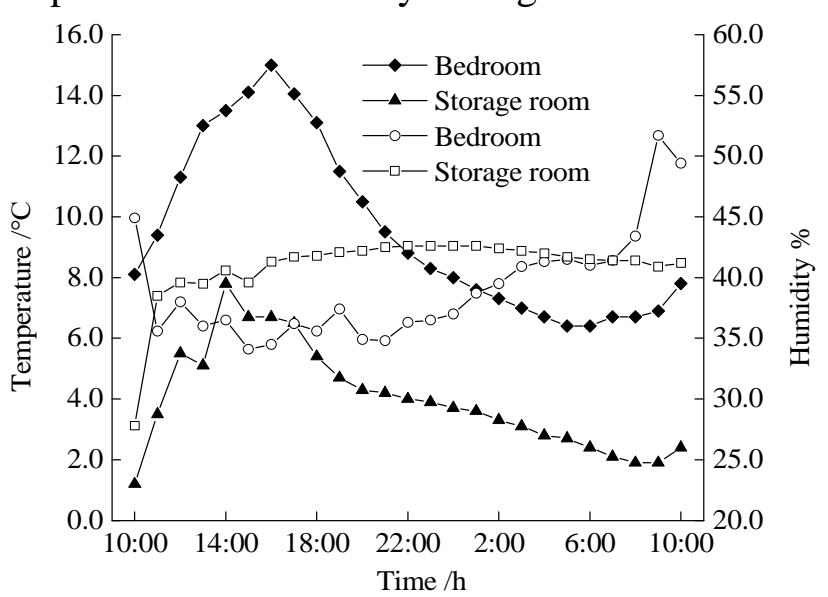

Fig. 4, The temperature and humidity of indoor

As you can see from Fig. 4, The average relative humidity of the main and secondary rooms (bedrooms, sundry rooms) is about $40 \%$, close to $40 \%$ to $70 \%$ of the lower limit of comfort [9]; but the overall indoor temperature is low, of which the main function room indoor temperature average of $9.5^{\circ} \mathrm{C}$, the secondary function room temperature average 4.0. In addition, the test data show that the indoor temperature fluctuation range of each function room is larger, the temperature fluctuation range of the main function room is $8.6{ }^{\circ} \mathrm{C}$, and the temperature fluctuation range of the function room is $6.6{ }^{\circ} \mathrm{C}$. Generally speaking, the indoor temperature of the main function room in the rural houses in Northwest China is higher than that in the secondary rooms, but the room temperature is generally low, and the temperature fluctuation is larger.

At the same time, the research group conducted a questionnaire on the satisfaction and thermal acceptance of indoor thermal environment, the results showed that: $68 \%$ of respondents think the winter indoor temperature is too low to feel comfortable, which is not that comfortable accounted for $43 \%$, in addition, the indoor air temperature limit of $80 \%$ residents acceptable value of $9{ }^{\circ} \mathrm{C}$, and that the secondary function room indoor air temperature can be $3{ }^{\circ} \mathrm{C}$ lower than the main function room.

It is not difficult to find that rural architecture has contained some of the ideas and means of the utilization of solar energy in the northwest, but because the building is still lack of scientific and systematic thermal design, the thermal performance of building envelope is poor, the indoor thermal environment in winter is not ideal, and the residents of thermal comfort satisfaction is low. 
Therefore, need to be combined with the specific situation in northwest rural area, optimizing the design of building structure to achieve the construction of solar energy collecting, storing sufficient and reasonable releasing and distributing, so as to improve the environmental quality of indoor thermal and thermal comfort of residents increased satisfaction.

\section{Rural solar energy building envelope structure optimization design}

Building model. Indoor thermal conditions of solar heating buildings are not only related to solar radiation intensity and outdoor air temperature, but also closely related to building parameters. According to the provisions of document $[10,11]$ construction parameters, the direct benefit of solar building the plane form, window wall ratio, enclosure structure and thermal parameters, and based on field research on rural construction in Ningxia area in recent years, the basic building model is close to the actual situation of the rural solar building in Northwest China the basic structure parameters, see Table 1.

Table 1, Basic building model and thermal parameters

\begin{tabular}{|c|c|c|c|c|c|c|c|c|c|c|c|}
\hline \multirow{2}{*}{$\begin{array}{l}\text { Building } \\
\text { style }\end{array}$} & \multirow{2}{*}{$\begin{array}{c}\text { Stories } \\
\text { high } \\
\text { /m }\end{array}$} & \multirow{2}{*}{$\begin{array}{c}\text { Area ratio } \\
\text { of south } \\
\text { window to } \\
\text { wall }\end{array}$} & \multirow{2}{*}{$\begin{array}{l}\text { Area ratio } \\
\text { of south } \\
\text { window } \\
\text { to wall }\end{array}$} & \multicolumn{2}{|c|}{$\begin{array}{l}\text { Plane size } \\
\qquad / \mathrm{m}\end{array}$} & \multicolumn{6}{|c|}{$\begin{array}{l}\text { Overall heat transfer coefficient of building envelope } \\
\qquad \mathrm{W} /\left(\mathrm{m}^{2} \cdot \mathrm{k}\right)\end{array}$} \\
\hline & & & & $\begin{array}{l}\text { East } \\
\text {-west } \\
\text { axis }\end{array}$ & $\begin{array}{c}\text { North } \\
\text {-south } \\
\text { axis }\end{array}$ & $\begin{array}{l}\text { Exterior } \\
\text { wall }\end{array}$ & Partition & Door & $\begin{array}{l}\text { Exterior } \\
\text { window }\end{array}$ & Roof & Ground \\
\hline Single & & & & & & & & & & & \\
\hline $\begin{array}{l}\text {-storey } \\
\text { three-bay }\end{array}$ & 3.0 & 0.5 & 0.2 & 18.5 & 8.6 & 1.54 & 1.65 & 2.70 & 4.70 & 2.56 & 0.30 \\
\hline
\end{tabular}

Solar radiation is a kind of intermittent low density energy, the total heat collection of buildings is relatively limited, so the heat energy is distributed evenly in the room, which will inevitably lead to the decrease of the utilization benefit and the thermal comfort level of the main function rooms [12]; in addition, Taking indoor space as a whole will simplify the process of thermal analysis, but it is insufficient to consider the difference of indoor thermal environment under the division of building function. According to the investigation of the basic space of the existing rural buildings in Northwest China and the residents' willingness to use the residential buildings, a typical indoor space model is identified, as shown in Fig. 5.

Based on the parameters in Table 1, a building physical model is built using a dynamic simulation software (Design, Builder) (as shown in Fig. 6). The model is a naturally run building, so the internal heat gain is not considered. Outdoor meteorological data are selected from typical meteorological year data of Ningxia Yinchuan.

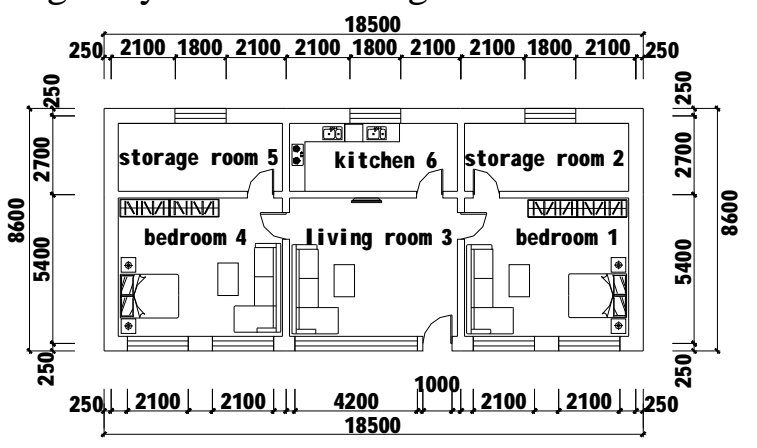

Fig. 5, Typical indoor space model

\begin{tabular}{|c|c|c|}
\hline Zone 5 & Zone 6 & Zone 2 \\
\hline Zone 4 & Zone 3 & Zone 1 \\
\hline
\end{tabular}

Fig. 6, Model plane diagram

Thermal parameter analysis and optimization of enclosure structure. After the outdoor thermal environment is determined, the indoor temperature of the specific building physical model is mainly 
affected by the window area ratio, the heat transfer coefficient of the external window, the heat transfer coefficient of the external wall, the heat transfer coefficient of the roof and so on. This paper will also analyze and optimize the envelope structure from these aspects.

The ratio of window wall area. Outside the window as a collection of building parts and heat loss components of the assembly, the south to the indoor average temperature increases with the window area ratio increases, but blindly increase the window wall area ratio will lead to excessive indoor temperature fluctuations, while the North window is because there is no thermal effect of direct solar radiation, the heat loss is large; at the same time different regions, different building model, the indoor temperature change trend with the area ratio of window to wall were also different. For the construction of a typical village of solar energy in Ningxia area, when the heat transfer coefficient of exterior wall is $1.54 \mathrm{~W} /\left(\mathrm{m}^{2} \cdot \mathrm{k}\right)$, north and south windows are used aluminum alloy single glass window, the change of natural running under the winter indoor temperature with the ratio of window to wall is shown in Fig. 7.

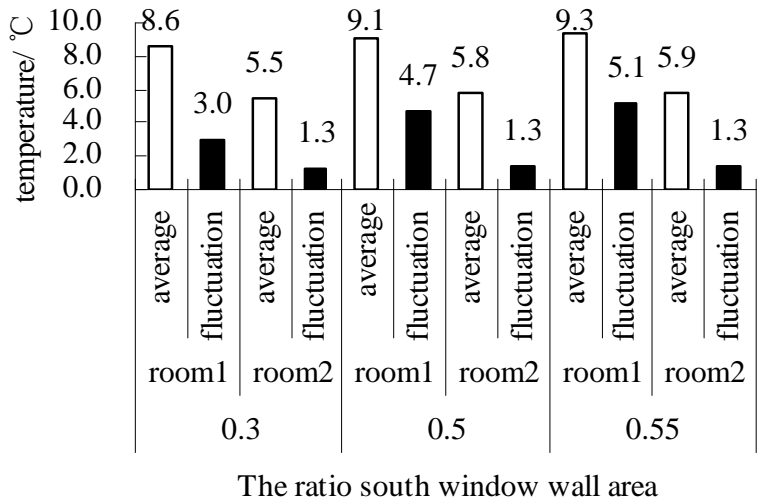

(a)
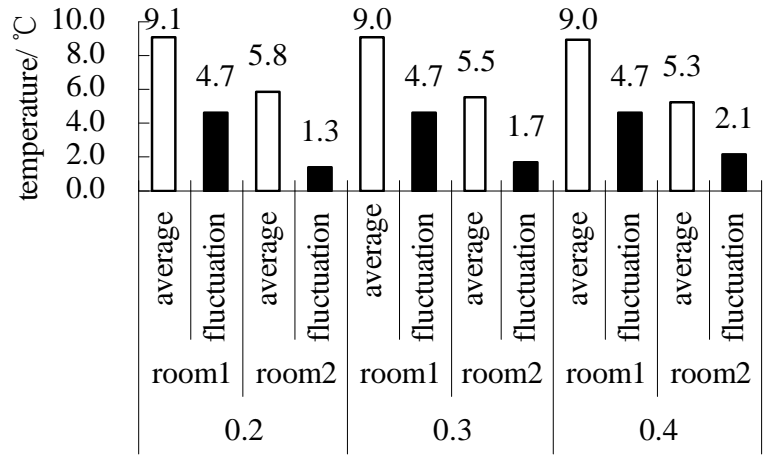

The ratio of north window wall area

(b)

Fig. 7, The influence of window wall area ratio on indoor temperature

As shown in Fig. 7 (a), with the increase of the ratio window to wall of the south, the indoor average temperature in the north and South rooms all are increased, but the temperature fluctuations in the south room is increased as well. When the window wall area ratio is increased from 0.30 to 0.55 , the average indoor temperature of the south room is increased by $0.7^{\circ} \mathrm{C}$, and the fluctuation range of temperature is increased by $2.2{ }^{\circ} \mathrm{C}$; meantime, the average indoor temperature of the north room is increased by $0.4{ }^{\circ} \mathrm{C}$, the temperature fluctuations basically unchanged. It can be seen that increasing the southward window wall ratio can significantly improve the indoor temperature of the south, but due to the cyclical characteristics of solar radiation, with the increasing ratio of the south window wall area, room indoor temperature fluctuation also increased. with the south to the window wall area ratio increases, the south room temperature fluctuations also increased. In reference [10], the area ratio of the south window to wall is recommended for the direct benefit type solar heating building, which is lower than the south window wall area. In this paper, the ratio of 0.5 to window to wall of the south is recommended.

As shown in Fig. 7 (b), with the increase of the ratio of the north to the window wall, the indoor average temperature of the room from north to South all are decreased, the temperature fluctuation in the north room is increased as well. When the window wall area ratio is increased from 0.2 to 0.4 , the south room indoor average temperature is decreased only $0.1{ }^{\circ} \mathrm{C}$, and the temperature fluctuations remain unchanged; but the indoor average temperature is reduced $0.5{ }^{\circ} \mathrm{C}$, the temperature fluctuation is increased by $1.8{ }^{\circ} \mathrm{C}$. It can be seen that the north out window is a net heat loss component, and the wall area ratio should be reduced as much as possible. According to China's "rural residential building energy-saving design standards" in GB/T50824-2013 on the 
north to the room area ratio of window to wall the provisions of [11], determining the North window wall area ratio of 0.2 , which take into consider lighting and ventilation of north room etc.

External window type and heat transfer coefficient. The outer window has an advantageous aspect of introducing solar radiant heat, but also has an disadvantageous aspect of heat transfering loss and cold air infiltrating loss. As far as the south window is concerned, it is not only the main heat collection component, but also the main heat sink at night. The outdoor thermal effect of the North window is different from that of the south. According to the outdoor meteorological conditions of Ningxia Yinchuan area, the paper chooses four conventional windows (see Table 3) and analysis its impact on the indoor temperature. When the south window wall area at the ratio of 0.5 , the north window wall area at the ratio of 0.2 , and the wall heat transfer coefficient is 1.54 $\mathrm{W} /\left(\mathrm{m}^{2} \cdot \mathrm{k}\right)$, the influence of these four types of windows (specific structural types and thermal parameters, see Table 2) on winter indoor temperature as shown in Fig. 8.

Table 2, External window type and heat transfer coefficient

\begin{tabular}{clccr}
\hline $\begin{array}{c}\text { Window frame } \\
\text { material }\end{array}$ & \multicolumn{1}{c}{$\begin{array}{c}\text { Outside the window } \\
\text { construction }\end{array}$} & $\begin{array}{c}\text { Heat transfer coefficient } \\
\mathrm{W} /\left(\mathrm{m}^{2} \cdot \mathrm{k}\right)\end{array}$ & $\begin{array}{c}\text { Effective area } \\
\text { coefficient }\end{array}$ & $\begin{array}{c}\text { Transmission } \\
\text { coefficient }\end{array}$ \\
\hline \multirow{2}{*}{ Aluminum alloy } & Single frame single glass & 6.40 & 0.80 & 0.76 \\
\cline { 2 - 5 } & Single frame double glass & 3.60 & 0.80 & 0.58 \\
\hline \multirow{2}{*}{ Plastic } & Single frame single glass & 4.70 & 0.70 & 0.76 \\
\cline { 2 - 5 } & Single frame double glass & 2.50 & 0.70 & 0.68 \\
\hline
\end{tabular}

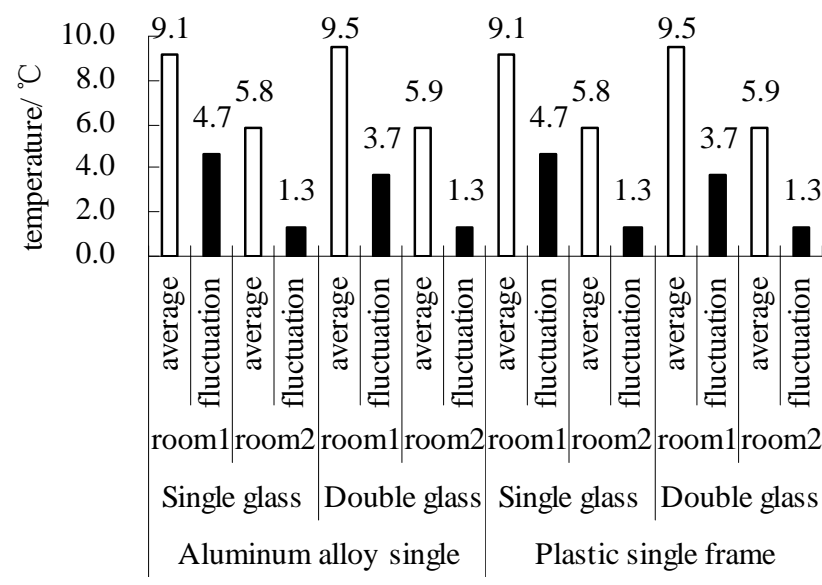

(a)

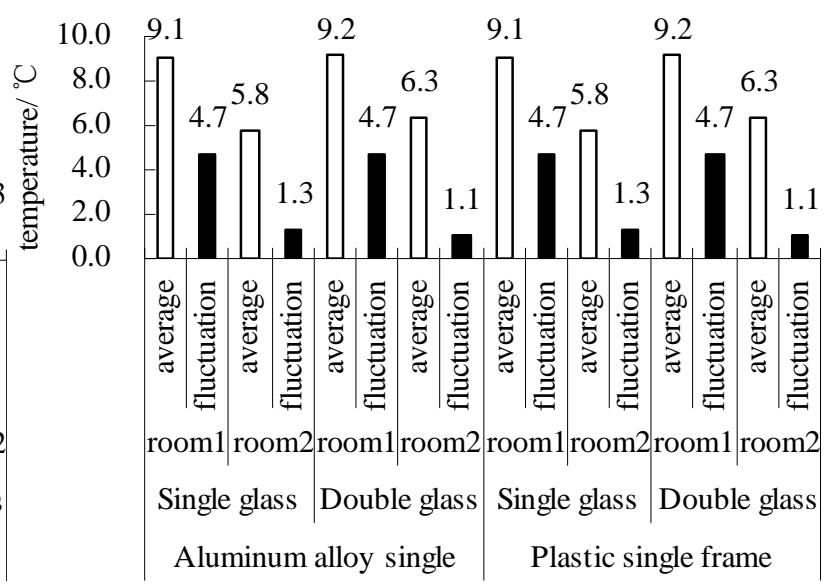

(b)

Fig. 8, The influence of exterior window type on indoor temperature

As shown in Fig. 8 (a), when the plastic window outside the south window is replaced by a plastic frame with low thermal conductivity, the average temperature and temperature fluctuation in the room of the north and South rooms are unchanged. With the Aluminum Alloy single box (single frame double glass or plastic) instead of a single glass, the corresponding room indoor average temperature and the temperature fluctuations part are increased by $0.4{ }^{\circ} \mathrm{C}$ and decreased by $1.0{ }^{\circ} \mathrm{C}$, but the north of the room temperature changes little. It can be seen that the indoor temperature of the south room is more obviously affected by the structure of the south window and the thermal parameters, by comparison, the room temperature in the north is basically the same.

As shown in Fig. 8 (b), the average temperature and temperature fluctuation in the room of the north and South rooms do not change when the plastic window is replaced by a plastic frame with a low thermal conductivity outside the North window. With the aluminum alloy single box (single frame double glass or plastic) instead of a single glass, corresponding to the north room indoor average temperature and the temperature fluctuations part are increased by $0.5^{\circ} \mathrm{C}$ and decreased by 
$0.2^{\circ} \mathrm{C}$, but south room temperature is kept constant. It can be seen that the indoor temperature of the north room is more obvious than that of the south window, By comparison, the indoor temperature of the south room is basically unchanged.

In summary, it can be seen that the window frame material has no influence on room temperature in Ningxia Yinchuan area, but the single frame double glass instead of single box single glass, the indoor average temperature will increase and the indoor temperature fluctuations will reduce, so selecting of a single box double glass window type for subsequent analysis.

External wall structure and heat transfer coefficient. External wall as the main part of the enclosure structure, the heat transfer coefficient of the exterior wall has a significant impact on building heat loss and indoor temperature [4]. In addition, compare with general heating buildings and single space solar building, solar building indoor and outdoor heat and heat transfer between the indoor space exist at the same time, so that the different orientation external wall thermal resistance change of indoor thermal environment will be different. Through the investigation of rural solar energy buildings in Ningxia, we can see that this rural area mostly adopts the self thermal insulation wall brick, lime sand brick and porous brick (Self - thermal insulation wall, referred to as "STI"), of course, a small building with sandwich insulation wall (Sandwhich insulation wall, referred to as "SI") [13]. The specific structural types and thermal parameters are shown in Table 3, and the effects of six representative structural walls on the indoor average temperature in winter are shown in Fig. 9.

Table 3, Types of wall structure and thermal parameters

\begin{tabular}{|c|c|c|c|c|c|c|}
\hline $\begin{array}{c}\text { Construction } \\
\text { type }\end{array}$ & & Material layer & $\begin{array}{c}\text { Thickness } \\
\text { /mm }\end{array}$ & $\begin{array}{c}\text { Thermal } \\
\text { conductivity } \\
\mathrm{W} /(\mathrm{m} \cdot \mathrm{k})\end{array}$ & $\begin{array}{c}\text { Density } \\
\mathrm{kg} / \mathrm{m}^{3}\end{array}$ & $\begin{array}{l}\text { Heat transfer } \\
\text { coefficien } \\
\mathrm{W} /\left(\mathrm{m}^{2} \cdot \mathrm{k}\right)\end{array}$ \\
\hline \multirow{6}{*}{ 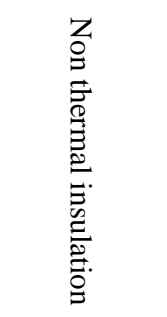 } & \multirow{2}{*}{ STI-1 } & Cement mortar (Inside + outside) & $20+20$ & 0.93 & 1800 & \multirow{2}{*}{1.54} \\
\hline & & Solid clay brick & 370 & 0.81 & 1800 & \\
\hline & \multirow{2}{*}{ STI-2 } & Cement mortar (Inside + outside) & $20+20$ & 0.93 & 1800 & \multirow{2}{*}{1.89} \\
\hline & & Lime sand brick & 370 & 1.10 & 1900 & \\
\hline & \multirow{2}{*}{ STI-3 } & Cement mortar (Inside + outside) & $20+20$ & 0.93 & 1800 & \multirow{2}{*}{1.20} \\
\hline & & KPI perforated bricks & 370 & 0.58 & 1400 & \\
\hline \multirow{9}{*}{ 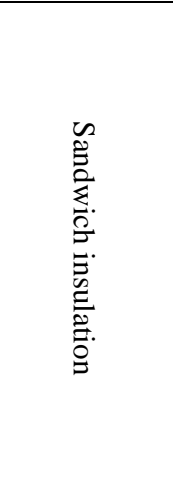 } & \multirow{3}{*}{ STI-1 } & Cement mortar (Inside + outside) & $20+20$ & 0.93 & 1800 & \multirow{3}{*}{0.82} \\
\hline & & Solid clay brick (Inside + outside $)$ & $240+120$ & 0.81 & 1800 & \\
\hline & & EPS insulation board & 80 & 0.041 & 100 & \\
\hline & \multirow{3}{*}{ STI-2 } & Cement mortar (Inside + outside) & $20+20$ & 0.93 & 1800 & \multirow{3}{*}{0.90} \\
\hline & & Lime sand brick (Inside + outside) & $240+120$ & 1.10 & 1900 & \\
\hline & & EPS insulation board & 80 & 0.041 & 100 & \\
\hline & \multirow{3}{*}{ STI-3 } & Cement mortar (Inside + outside) & $20+20$ & 0.93 & 1800 & \multirow{3}{*}{0.70} \\
\hline & & KPI perforated bricks (Inside + outside) & $240+120$ & 0.58 & 1400 & \\
\hline & & EPS insulation board & 80 & 0.041 & 100 & \\
\hline
\end{tabular}




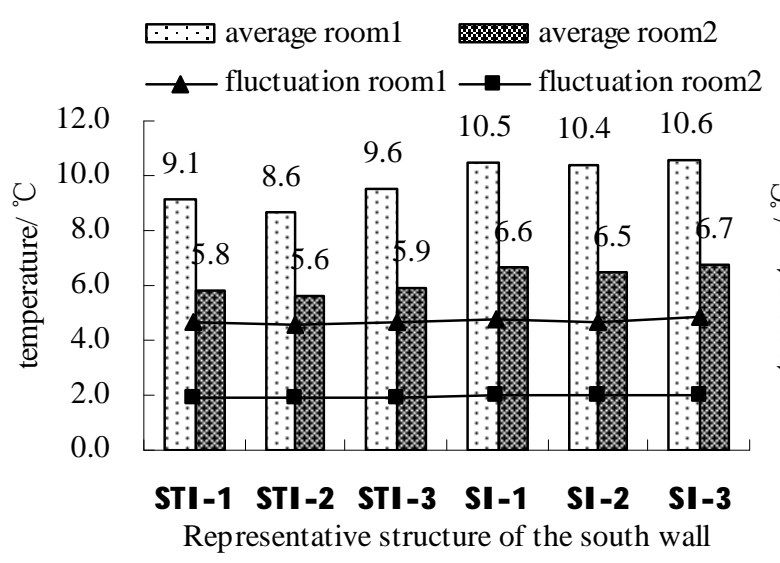

(a)

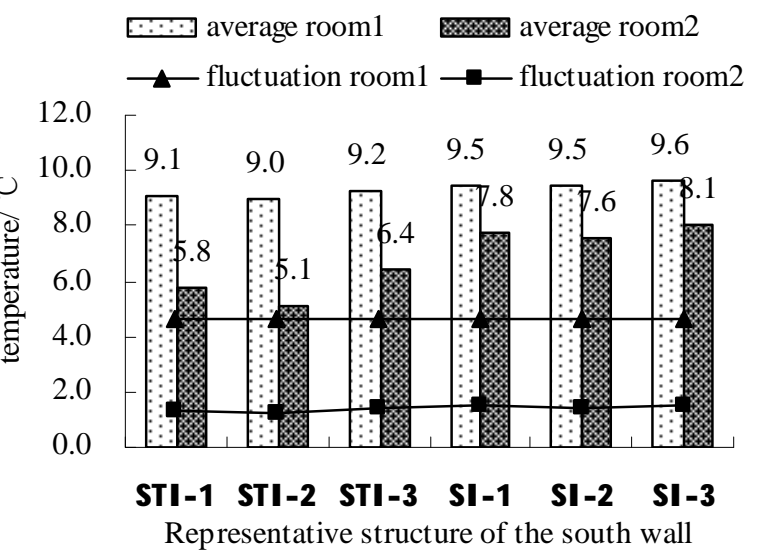

(b)

Fig. 9, The Influence of exterior wall type on indoor temperature

As shown in Fig. 9 (a), when the area ratio of the window to the window is 0.5 and 0.2 respectively, the room temperature all changes of the north and south of the building under the different heat transfer coefficients. It can be seen from the diagram that the indoor average temperature of the north and south rooms all increases with the decrease of the heat transfer coefficient of the South outer wall, and the fluctuation range of indoor temperature varies little. When the south wall heat transfer coefficient from $1.89 \mathrm{~W} /\left(\mathrm{m}^{2} \cdot \mathrm{k}\right)$ is reduced to $0.7 \mathrm{~W} /\left(\mathrm{m}^{2} \cdot \mathrm{k}\right)$, the average indoor temperature of the south room is increased by $1.5^{\circ} \mathrm{C}$, the temperature fluctuation is increased by $0.3{ }^{\circ} \mathrm{C}$; the average indoor temperature of the north room is increased by $0.9{ }^{\circ} \mathrm{C}$, the temperature fluctuations basically unchanged. It can be seen that the average temperature of the interior of the south room increases obviously, and the range of temperature fluctuation remains basically unchanged when the heat transfer coefficient of the south wall is decreased. However, when the SI-2 type structure is used instead of the SI-3 type structure in the South outer room, the average indoor temperature in the north and South rooms only is increased by $0.1{ }^{\circ} \mathrm{C}$. Combination with the local economic situation, it is suggested that the SI-2 structure be adopted for the South outer wall.

As shown in Fig. 9 (b), when the area ratio of the window wall area is 0.5 and 0.2 respectively, the room temperature all changes of the north and south of the building under the different heat transfer coefficients. As can be seen from the diagram, the average indoor temperature of all rooms are increases with the decrease of the coefficient of heat transfer to the north wall, and the fluctuation range of indoor temperature more little. When the south wall heat transfer coefficient from $1.89 \mathrm{~W} /\left(\mathrm{m}^{2} \cdot \mathrm{k}\right)$ is reduced to $0.7 \mathrm{~W} /\left(\mathrm{m}^{2} \cdot \mathrm{k}\right)$, the average indoor temperature of the north room is increased by $2.3^{\circ} \mathrm{C}$, the temperature fluctuation is increased $0.2{ }^{\circ} \mathrm{C}$; the average indoor temperature of the north room is increased by $0.5^{\circ} \mathrm{C}$, the temperature fluctuations basically unchanged. It can be seen that the heat transfer coefficient of the north wall is reduced, and the indoor temperature of the room is obviously increased, and the range of temperature fluctuation remains basically unchanged.

In summary, it can be seen that the indoor average temperature is improved remarkably after the heat transfer coefficient of the exterior wall is reduced, and the fluctuation range of indoor temperature varies little. At the same time, combination with the local rural economic conditions, In the paper, the south exterior wall is selected as the SI-2 structure and the north exterior wall is selected as the SI-3 structure for further analysis.

Roof structure and heat transfer coefficient. Roof as the top of the building envelope, with insulation, heat insulation and waterproof such as multiple roles. With the increasing demand for building energy efficiency, energy-saving roof has been developed and popularized rapidly. In 
addition, extensive application of high efficiency insulation materials, not only improves the energy-saving effect of roofing but also promotes the development of roofing structure, meantime, inverted roof is a more advanced and scientific way of construction. [14]. To sum up, in this paper, the use of inverted roof structure and select the expansion of polystyrene board as insulation materials. Three typical structural roofs (specific structural types and thermal parameters) are shown in Table 4. The influence of indoor mean temperature in winter is shown in Fig. 10.

Table 4, Roof construction practices and thermal parameters

\begin{tabular}{|c|c|c|c|c|c|c|}
\hline & Material layer & $\begin{array}{c}\text { Thickness } \\
\text { /mm }\end{array}$ & $\begin{array}{c}\text { Thermal } \\
\text { conductivity } \\
\mathrm{W} /(\mathrm{m} \cdot \mathrm{k})\end{array}$ & $\begin{array}{c}\text { Density } \\
\mathrm{kg} / \mathrm{m}^{3}\end{array}$ & $\begin{array}{c}\text { Specific heat } \\
(\mathrm{J} / \mathrm{kg} \cdot \mathrm{K})\end{array}$ & $\begin{array}{l}\text { Thermal } \\
\text { resistance } \\
\left(\mathrm{m}^{2} \cdot \mathrm{K} / \mathrm{W}\right)\end{array}$ \\
\hline (1) & Cement mortar protective layer & 30 & 0.93 & 1800 & 1050 & 0.032 \\
\hline \multirow{3}{*}{ (2) } & \multirow{3}{*}{ Extruded polystyrene board insulation layer } & 20 & \multirow{3}{*}{0.03} & \multirow{3}{*}{30} & \multirow{3}{*}{1380} & 1.333 \\
\hline & & 50 & & & & 2.000 \\
\hline & & 80 & & & & 2.462 \\
\hline (3) & Waterproof layer & 6 & 0.17 & 600 & 1470 & 0.036 \\
\hline (4) & Screed layer of cement mortar & 20 & 0.93 & 1800 & 1050 & 0.022 \\
\hline (5) & Cement expanded perlite for slope finding & 30 & 0.26 & 800 & 1170 & 0.115 \\
\hline ๑) & Steel reinforced concrete & 100 & 1.74 & 2500 & 920 & 0.057 \\
\hline (7) & Plastering of cement mortar & 20 & 0.93 & 1800 & 1050 & 0.022 \\
\hline
\end{tabular}

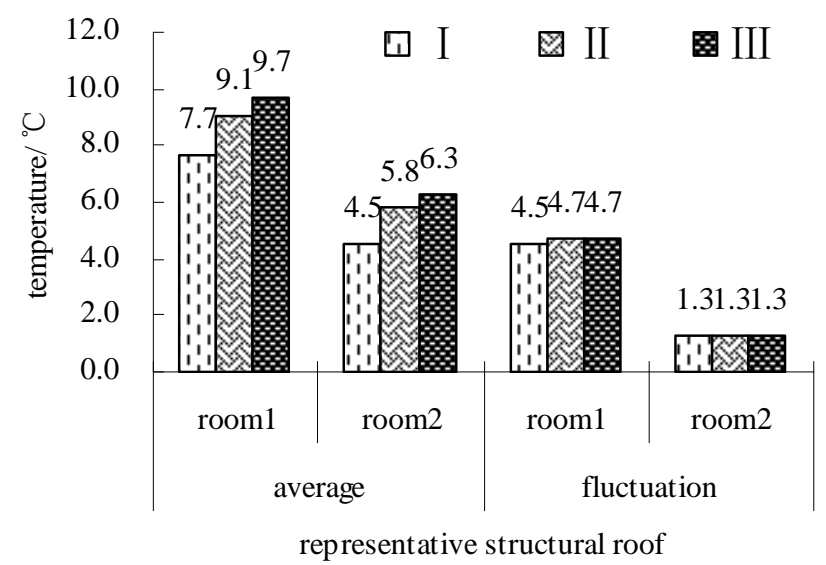

Fig. 10, The influence of roof type on indoor temperature

It can be seen from Fig. 10, with the roof heat transfer is reduced, the average temperature of the room to the north and south are increased, and the temperature fluctuation range remained essentially unchanged When the heat transfer coefficient by $0.92 \mathrm{~W} /\left(\mathrm{m}^{2} \cdot \mathrm{k}\right)$ is reduced to 0.32 $\mathrm{W} /\left(\mathrm{m}^{2} \cdot \mathrm{k}\right)$, the south room average indoor temperature is increased by $2.0{ }^{\circ} \mathrm{C}$, the temperature fluctuations is increased by $0.2{ }^{\circ} \mathrm{C}$; meantime, the north room average indoor temperature is increased by $1.8^{\circ} \mathrm{C}$, but the temperature fluctuations remain unchanged. Therefore, the decrease of roof heat transfer coefficient is beneficial to the improvement of indoor average temperature, and the range of temperature fluctuation is basically unchanged. Therefore, 3 structural type of roof is selected for further analysis.

Comparison and analysis of room temperature simulation. According to the structure of the building envelope shown in Table 5 to modify the model parameters, the indoor temperature of the original dwellings and the improved dwellings are simulated respectively, The comparison results are shown in Fig. 11. 
Table 5, The building construction of original residence and improved residence

\begin{tabular}{|c|c|c|c|}
\hline \multicolumn{2}{|c|}{$\begin{array}{l}\text { Overall heat transfer coefficient of } \\
\text { building envelope }\end{array}$} & Original residence & Improved residence \\
\hline \multirow{2}{*}{ Exterior window } & South & $\begin{array}{c}\text { Single-frame single glass, window wall } \\
\text { area ratio of } 0.4\end{array}$ & $\begin{array}{c}\text { Single-frame single glass, window wall } \\
\text { area ratio of } 0.5\end{array}$ \\
\hline & North & $\begin{array}{c}\text { Single-frame single glass, window wall } \\
\text { area ratio of } 0.4\end{array}$ & $\begin{array}{c}\text { Single-frame single glass, window wall } \\
\text { area ratio of } 0.2\end{array}$ \\
\hline \multirow{2}{*}{ Exterior wall } & South & $\begin{array}{l}\text { STI-1 construction type, heat transfer } \\
\text { coefficient of } 1.54 \mathrm{~W} /\left(\mathrm{m}^{2} \cdot \mathrm{k}\right)\end{array}$ & $\begin{array}{l}\text { STI-2 construction type, heat transfer } \\
\text { coefficient of } 0.82 \mathrm{~W} /\left(\mathrm{m}^{2} \cdot \mathrm{k}\right)\end{array}$ \\
\hline & North & $\begin{array}{l}\text { STI-1 construction type, heat transfer } \\
\text { coefficient of } 1.54 \mathrm{~W} /\left(\mathrm{m}^{2} \cdot \mathrm{k}\right)\end{array}$ & $\begin{array}{l}\text { STI-3 construction type, heat transfer } \\
\text { coefficient of } 0.70 \mathrm{~W} /\left(\mathrm{m}^{2} \cdot \mathrm{k}\right)\end{array}$ \\
\hline \multicolumn{2}{|c|}{ Roof } & $\begin{array}{l}\text { Without heat preservation, the coefficient } \\
\text { of heat transfer is } 2.56 \mathrm{~W} /\left(\mathrm{m}^{2} \cdot \mathrm{k}\right)\end{array}$ & $\begin{array}{l}\text { IIIconstruction type, the coefficient of } \\
\text { heat transfer is } 0.32 \mathrm{~W} /\left(\mathrm{m}^{2} \cdot \mathrm{k}\right)\end{array}$ \\
\hline
\end{tabular}

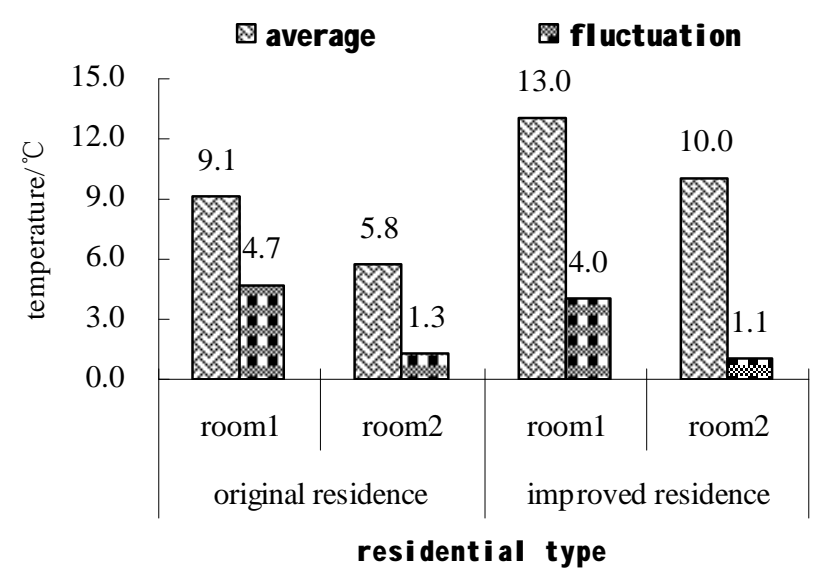

Fig. 11, Indoor temperature comparison of original residence and improved residence

Fig. 11 shows the indoor temperature contrast of two types of dwellings. It can be seen that the average indoor temperature of residential buildings is higher than that of the former dwellings, and the temperature fluctuation is smaller. The south room average indoor temperature is increased by $3.9^{\circ} \mathrm{C}$, the temperature fluctuation is increased by $0.7^{\circ} \mathrm{C}$; meantime, the north room average indoor temperature is increased by $4.2^{\circ} \mathrm{C}$, the temperature fluctuation is decreased by $2.9^{\circ} \mathrm{C}$. It can be seen that compared with the former dwellings, the quality of indoor thermal environment in residential buildings has been greatly improved without additional energy consumption.

As the room selected by the room (room1, room2) were the east side of the building north and south to get the most unfavorable room, and the analysis of indoor thermal environment selected outdoor weather data for the typical winter solstice, we can see that the whole building of each function room indoor thermal environment quality can reach the requirements of the North West Rural Residents of indoor thermal comfort standard.

\section{Conclusions}

(1) The northwest winter is cold, but the solar energy resources are rich, and it has the regional advantages to develop passive solar energy buildings. (2) Although the rural buildings in this area contain some ideas and means of solar energy utilization, due to the lack of scientific design, the thermal performance of the building envelope is poor, the indoor thermal environment is poor, and the residents' satisfaction is low. (3) Combined with the local rural specific situation, through the 
optimization of building envelope construction, the south room average indoor temperature is increased by $3.9{ }^{\circ} \mathrm{C}$, the temperature fluctuations is increased to $0.7^{\circ} \mathrm{C}$; the north room average indoor temperature is increased by $4.2{ }^{\circ} \mathrm{C}$, the temperature fluctuation decreased by $2.9{ }^{\circ} \mathrm{C}$; Compared with the original residential, without increasing the energy consumption in the case, The indoor thermal environment quality of improved residence has been greatly improved, and reached the Northwest rural residents satisfied with the indoor thermal comfort standards.

\section{Acknowledgements}

This work was supported by the National Natural Science Foundation of China (51378424、 51678482).

\section{References}

[1] Zhang Qun, Liang Rui, Liu Jiaping: Journal of Xi'an University of Technology. 31(2) (2011), p. $172-176$

[2] Liu Dalong, Liu Jiaping, Yang Liu. et al: Industrial Construction. 42(2) (2012), p. 19-22

[3] Zhou Yang, Wu Wenxiang, Hu Ying. et al: Journal of Natural Resources. 25(10) (2012), p. 1738-1749

[4] Sang Guochen, Liu Jiaping: Acta energiae solaris sinica. 32(03) (2011), p. 416-422

[5] Li Yanjun: Journal of Xi'an University of Architecture and Technology. (2014)

[6] Ma Chao, Liu Yanfeng, Wang Dengjia. et al: Journal of Xi'an University of Architecture and Technology. 47(03) (2015), p. 427-432

[7] Zhu Yiyun, Liu Jiaping: China Civil Engineering Journal. 43(SI) (2010), p. 400-403

[8] Zhang Qun, Zhu Yiyun, Liu Jiaping. et al: Journal of Xi'an University of technology, 07(08) (2010), p. 477-481

[9] Yang Liu : Building climatology (China Architecture \& Building Press, Beijing 2009)

[10] JGJ/T267-2012 Technical specification for passive solar building (Architecture \& Building Press, Beijing 2012)

[11] GB/T50824-2013 Standard for energy efficiency design of rural residential buildings(China Architecture \& Building Press, Beijing 2013)

[12] Sang Guochen, Han Yan, Zhu Yiyun. et al: Acta energiae solaris sinica. 37(11) (2016), p. 903-2908

[13] Sang Guochen, Han Yan, Zhu Yinyun. et al: Journal of Xi'an University of Technology. 32(01) (2016), p. 30-34

[14] Sang Guochen: Journal of Xi'an University of Architecture \& Technology. (2009) 